\title{
Ocular Biomarkers for Early Detection of Alzheimer's Disease
}

Shaun Frost ${ }^{\mathrm{a}, \mathrm{b}, \mathrm{c}}$, Ralph N Martins ${ }^{\mathrm{b}, \mathrm{d}, \mathrm{e}}$, Yogesan Kanagasingam $^{\mathrm{a}, \mathrm{c}}$

${ }^{a}$ Centre for Ophthalmology and Visual Sciences, University of Western Australia, 35 Stirling Highway, Crawley, WA 6009, Australia.

${ }^{b}$ School of Psychiatry and Clinical Neurosciences, University of Western Australia, Crawley, WA 6009, Australia.

${ }^{c}$ Commonwealth Scientific and Industrial Research Organisation (CSIRO), Australian E-Health Research Centre, 65 Brockway Rd, Floreat, WA 6014, Australia.

${ }^{d}$ Sir James McCusker Alzheimer's Disease Research Unit, Hollywood Private Hospital, Nedlands, WA 6009, Australia

${ }^{e}$ School of Exercise, Biomedical and Health Sciences, Edith Cowan University, Joondalup, WA 6027, Australia.

\section{Correspondence to:}

Professor Ralph Martins, Sir James McCusker Alzheimer's Disease Research Unit, 184 Hampden Rd, Nedlands, WA 6009, Australia.

Tel: (61 8) 93466703 Fax: (61 8) 63045851

E-mail: r.martins@ecu.edu.au

Running Title: The eye and Alzheimer's disease. 


\begin{abstract}
Alzheimer's disease (AD) is the most common form of dementia and is characterized clinically by a progressive decline in memory, learning and executive function and neuropathologically by the presence of cerebral amyloid deposits. Despite a century of research, there is still no cure or conclusive pre-mortem diagnosis for the disease. A number of symptom-modifying drugs for AD have been developed, but their efficacy is minimal and short-lived. $A D$ cognitive symptoms arise only after significant, irreversible neural deterioration has occurred, hence there is an urgent need to detect $A D$ early, before the onset of cognitive symptoms. An accurate, early diagnostic test for AD would enable current and future treatments to be more effective, as well as contribute to the development of new treatments.

While most $A D$ related pathology occurs in the brain, the disease has also been reported to affect the eye, which is more accessible for imaging than the brain. AD-related proteins exist in the normal human eye and may produce ocular pathology in AD. There is some homology between the retinal and cerebral vasculatures and the retina also contains nerve cells and fibers that form a sensory extension of the brain. The eye is the only place in the body where vasculature or neural tissue is available for non-invasive optical imaging. This article presents a review of current literature on ocular morphology in $A D$ and discusses the potential for an ocular based screening test for AD.
\end{abstract}

\title{
Keywords:
}

Retinal, vision disorders, cataract, lens, amyloid beta protein, aging, diagnosis 


\section{Contents}

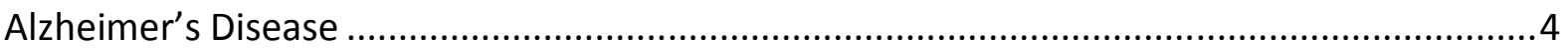

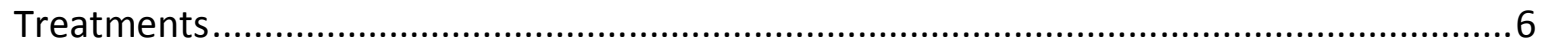

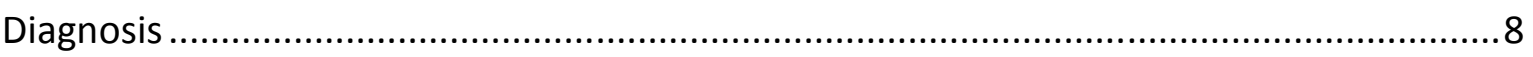

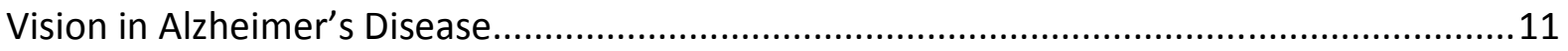

Ocular Biomarkers for Early Detection of Alzheimer's Disease ..........................................12

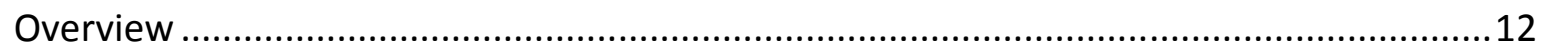

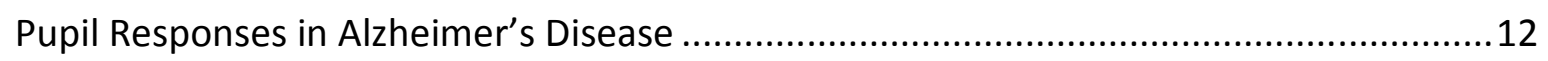

The Ocular Lens and Vitreous Humor in Alzheimer's Disease........................................14

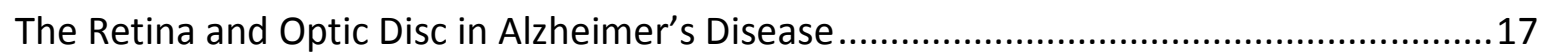

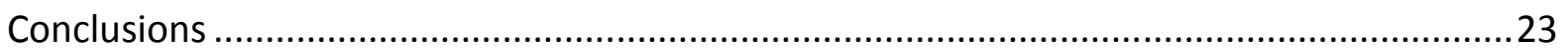

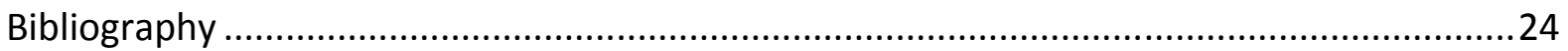




\section{Alzheimer's Disease}

Alzheimer's Disease (AD) is the most common form of dementia, affecting more than 26 million people worldwide [1]. The disease is characterized clinically by a progressive decline in memory, learning and executive function and neuropathologically by the presence of cerebral amyloid deposits. In addition to the debilitating symptoms endured by AD patients, the disease imposes a huge social and economic burden on society. AD is an incurable, degenerative and terminal disease usually diagnosed in people over 65 years of age [2]. It affects $5 \%$ of people aged 65 and $20-40 \%$ of those aged 85 . The late-onset form of $A D$ (LOAD) is the most common form of the disease and in the majority of cases, where there is no evidence of it being inherited, it is termed "sporadic $A D$ ". A rare form of $A D$, termed "early-onset familial $A D$ " (EOFAD), is inherited in an autosomal dominant manner, and can occur in people as young as 30 years of age. Mild Cognitive Impairment (MCl) is considered a prodromal phase of $A D$, with $40-60 \%$ of people meeting criteria for $\mathrm{MCl}$ eventually progressing to $A D$, or about $5-25 \%$ per year [3].

$A D$ is histopathologically characterized by a substantial loss of neurons in the brain, atrophy of the brain, as well as the deposition of extracellular amyloid $\beta$ (AB) plaques and intracellular neurofibrillary tau tangles (NFT) [4]. The factors that may cause or accelerate the development of $A D$ are not fully understood, and the exact contribution of plaques and tangles in causing symptoms of $A D$ also remain to be established. General consensus in the field supports the "Amyloid Cascade Hypothesis", which states that an imbalance in A $\beta$ metabolism in the brain is the fundamental cause of the neurodegeneration and cognitive decline in $A D$, though many studies suggest this effect of $A \beta$ is at least partly mediated by increased tau phosphorylation. In recent years, much evidence has been gathered to show that several factors contribute to the risk of developing AD. These include diabetes, mid-life 
obesity, and a history of heart disease or symptoms typically associated with heart disease such as high levels of low density lipoproteins (LDL) together with low levels of high density lipoproteins (HDL) [5].

The major protein component of the amyloid plaques is a peptide known as amyloid $\beta(A \beta)$. $A \beta$ peptides range from 39 to 43 amino acid residues in length. The longer ( $A \beta 42$ or $A \beta 43$ ) peptides aggregate easily into fibrils, and small soluble oligomers of $A \beta$ are believed to be a neurotoxic form of $A \beta$, whereas the large insoluble aggregates and plaques are relatively inert [6]. The $A \beta$ peptide is proteolytically derived from its parent molecule, the amyloid- $\beta$ protein precursor (AßPP). A $\mathrm{APP}$ is an integral membrane protein that has been implicated in blood clotting [7] and as a regulator of neural plasticity and post-injury repair [8]. A $\beta$ peptides are produced as a result of sequential cleavage of A PPP by enzymes known as the $\beta$-secretase (also known as $\beta$-site A $\beta$ PP cleavage enzyme or BACE) and $\gamma$-secretase, respectively. The most common form is $A \beta 40$, but it is the second most common form, $A \beta 42$, which is more fibrillogenic and is thus associated with disease states [9].

$A \beta$ has been shown to have a constrictive effect on the cerebral vasculature [10], and interestingly, to be neuroprotective at low physiological concentrations [11]. For this reason $A \beta$ has been suggested to have a dual damage response role in the brain, by sealing the vasculature reducing brain oxygen requirement and combating oxidative stress [12]. A recent study also demonstrated that $A \beta$ has significant antimicrobial ability against clinically relevant organisms, introducing an interesting hypothesis that infection might have a role in some forms of $A D$ [13]. Whatever the role of $A \beta$ in the healthy body, a large number of in vitro and in vivo $A D$ studies, particularly those of EOFAD, have shown that higher than normal $A \beta$ levels cause oxidative stress in the brain, resulting in synaptic loss, cell membrane damage, inflammation and ultimately result in neuronal cell death [14-15]. Such 
studies have shown that EOFAD-associated mutations in the AßPP gene or the presenilin 1 and 2 genes (presenilin being an essential component of the $\gamma$-secretase enzyme) have been found either to increase total $A \beta$ levels or to increase the production of $A \beta 42$ [16-17]. Such increases in $A \beta$ levels have been implicated in the pathogenesis of both familial and sporadic AD [14-15].

NFT are insoluble, twisted fibers of a protein called tau. Phosphorylated tau stabilizes the internal structure of healthy neurons, but in $A D$, tau proteins are hyperphosphorylated and tangle together. Again, recent evidence points to soluble tau rather than NFT as a cause of neuronal loss in $A D$ [18-20]. When researchers turned off the mutant tau gene in a mouse model of $A D$, neurodegeneration was halted and cognitive performance improved even though NFT continued to accumulate [19]. While tau hyperphosphorylation is not specific to $A D$, there is strong evidence to indicate that it is essential for $A \beta$-induced cognitive decline to occur.

\section{Treatments}

At present there is no cure or disease modifying drug to effectively treat $A D$, but there are drugs that have proven to be beneficial at the level of reducing some symptoms for up to 18 months. There is an urgent need for effective treatments, with the number of cases worldwide forecast to exceed 100 million by 2050 [1]. Currently available drugs can delay or alleviate symptoms but do not slow the progression of the disease as they do not target the underlying cause. Pharmaceutical drugs currently available to treat the cognitive manifestations of $A D$ include acetylcholinesterase inhibitors and an NMDA receptor antagonist. Research is continuing into drugs designed to prevent or reduce $A \beta$ production, 
to break up $A \beta$ plaques or to prevent metal ion-A $\beta$ interactions which may acccelerate $A \beta$ aggregation [21-22]. For example, one suggested avenue of treatment involves modulating the activity of $\beta$ and $\gamma$-secretases to produce mainly $A \beta 40$ instead of the more harmful $A \beta 42$ peptide. In other studies, immunizing transgenic $A D$ mouse models with human $A \beta 42$ peptide was found to prevent the build-up of $A \beta$ plaques [23] which was associated with prevention of memory impairment, yet a successful outcome was not achieved in early clinical studies due to serious side-effects. However, immunotherapies that either prevent plaque deposition or enhance removal of plaques are still being actively investigated by pharmaceutical companies with a number of them in either phase II or III clinical trials. Antiaggregation agents with the aim of removing plaques and/or preventing $A \beta$ fragments from aggregating are also being examined [24] and are expected to enter clinical trials within the next 12 months.

In 2008, a discontinued Russian antihistamine drug Dimebon (latrepiridine) was found to stabilize cognitive and functional activity in AD patients [25]. However, this phase II study outcome has since been thrown into question by negative results from subsequent phase III trials [26]. Differences between the studies include mean age and cognitive performance of participants as well as the source of Dimebon. Further studies are now being conducted to determine the efficacy of Dimebon in conjunction with other drugs to treat AD. Dimebon inhibits cholinesterase and NMDA receptors and may enhance neuronal function and survival through its effects on mitochondria. Other non-pharmacological therapeutic approaches are currently being investigated. Of these, lifestyle modification, particularly physical activity, nutrition and mental stimulation are gaining considerable attention in the field. It has been demonstrated that a cognitively stimulating environment can reduce $A \beta$ deposition in transgenic mice [27], and that increased cognitive activity in humans can 
reduce the risk of $A D$ [28]. A possible explanation for the mechanism by which cognitive stimulation might delay onset of $A D$ has been identified [29]: researchers found that synaptic activity increases $A \beta$ in local interstitial fluid. Cognitive stimulation transfers electrical activity away from brain regions with high 'default activity', hence reducing $A \beta$ levels in these regions - particular regions which in fact end up with high levels of $A \beta$ deposition in AD [30].

The above-mentioned treatments can be made available for $A D$ patients only after they have been clinically diagnosed with the disease. Unfortunately $A D$ is difficult to diagnose with absolute certainty. In addition, the cognitive symptoms on which diagnosis is based only become apparent after irreversible brain damage has already occurred. Hence the search for better AD treatments needs to be coupled with research into early detection of the disease.

\section{Diagnosis}

There is currently no definitive pre-mortem diagnosis for AD. Conclusive diagnosis of $A D$ is only achieved following post-mortem examination of the brain for the presence plaques and tangles in the brain. A pre-mortem diagnosis of "probable $A D$ " is currently made by clinical observations and testing of cognitive capacity and memory loss. Other dementias and conditions such as depression can have similar symptoms, thus confounding diagnosis [31]. A diagnostic error rate of about $10-15 \%$ has been reported for $A D$ [32].

A diagnosis of probable $A D$ is only possible when the condition has progressed and considerable neurological damage has already occurred. The increasing frequency of $A D$ in the population, along with the need to treat the disease before cognitive symptoms arise, 
calls for a sensitive and specific screening technology to identify high risk individuals before the brain is irreversibly damaged.

Biomarkers that have shown promise for the early detection of $A D$ include a reduction in brain and specifically hippocampal volume (using MRI - magnetic resonance imaging), changes to brain function (using functional MRI) and changes in the concentrations of $A \beta 40$, $A \beta 42$ or tau in the cerebrospinal fluid (CSF). CSF biomarkers have proven to be the most accurate of the biomarkers investigated to date, with AD being shown to be associated with decreased A642 levels and increased tau levels in the CSF [33]. However the latter procedure is invasive and patient compliance is anticipated to be low.

Another promising approach is PET imaging employing ligands, such as Pittsburgh Compound-B (PIB), which selectively bind to $A \beta$ plaques in vitro and in vivo, enabling plaque load to be imaged in living patients [31-33]. Interestingly, many $\mathrm{MCl}$ and a significant percentage (30\%) of cognitively normal elderly individuals show high brain retention of PIB and low AB42 levels in the CSF [34-35]. Further follow-up studies are required to determine if this identifies those individuals that will go on to develop $A D$, with one recent study supporting this hypothesis [36].

As mentioned earlier, in terms of genetic markers, certain mutations in A $\beta P P$, presenilin 1 and presenilin 2 are known to cause EOFAD [16-17]. One major genetic risk factor for sporadic AD has been known for some time, the apolipoprotein E (APOE) $\varepsilon 4$ gene [37]. APOE $\varepsilon 4$ has been implicated in modulating the metabolism and aggregation of $A \beta$ [38]. Individuals with one copy of the APOE- $\varepsilon 4$ allele have a 2-3 fold increased risk of developing AD by age 85 and those with two copies have a 12 fold increased risk compared to the general population [39]. 
Recent genetic association studies have revealed three more genes linked to $A D$, the Clusterin, PICALM and CR1 genes [40-41]. Also, a recent meta-analysis has found more than 20 genes that have a significant effect on $A D$ risk [42]. However, while these genes may contribute to identifying high risk individuals, they are not sufficient on their own to make a diagnosis, nor is the major genetic risk factor, APOE $\varepsilon 4$, which is associated with up to $50 \%$ of all AD cases. Hence genetic profiling is emerging as a technique for predicting the risk of an individual getting $A D$ rather than providing diagnostic markers. It is possible that a panel of genetic and biological factors may together prove useful in determining high risk individuals.

Important properties of a biomarker for screening are sensitivity and specificity for the relevant disorder, as well as practicality of the biomarker measurement. Evaluation of the sensitivity and specificity of $A D$ biomarkers involves comparison of biomarker measurements in $A D$ cases and controls. Evaluation of potential $A D$ biomarkers is thus hampered by the $10-15 \%$ diagnostic error rate in AD [32]. Studies incorporating postmortem confirmation of $A D$ can avoid this problem, but for most studies this is not possible, hence this diagnostic inaccuracy should be considered when interpreting results. A significant number of healthy controls (30\%) may be high-risk clinically silent individuals, further confounding interpretation [43-44].

The combination of different biomarkers can increase sensitivity and specificity; combining CSF $A \beta 42$ and tau parameters increases sensitivity and specificity above $80 \%$. Indeed Simonsen et al. [45] found a panel of 5 CSF biomarkers for AD which when combined gave $100 \%$ sensitivity and $97 \%$ specificity on blinded independent data [45]. However, this study compared AD cases with healthy controls and hence doesn't provide information about the specificity of the test against other dementias or diseases. In terms of practicality, lumbar 
punctures for CSF fluid samples are expensive, invasive and patient non-compliance is a major issue. Neuro-imaging (MRI, PET, CT) is also expensive and the number of facilities available for clinical use is not adequate for population screening. Therefore there is a need for new AD biomarkers that are more practical as well as more sensitive and specific. The absence of a suitable screening technology for AD has motivated some researchers to look for biomarkers that might exist elsewhere in the body, including the eye.

\section{Vision in Alzheimer's Disease}

Visual disturbance is often an early complaint of AD patients [46-47] and studies have reported reduced visual performance on tests of visual field [48-49], color vision [50-52], contrast sensitivity [53-55], backward masking [56-57], visual attention, motion perception, shape-from motion, visuo-spatial construction, visual memory [58-60], delayed saccadic initiation and movement and fixation problems [47, 61-63]. However, none of these deficiencies are specific to AD. The current literature is controversial and reflects the need for larger and more rigorous studies to be undertaken before the significance of this interesting approach for AD-screening can be conclusively evaluated.

Reported visual deficits in AD have generally been attributed to neuronal damage in the visual pathways of the brain [64-65] as well as deficiency of the neurotransmitter acetylcholine in $A D$, which is important in visual processing [66-68]. Indeed there is evidence that during the pathogenesis of $A D$, plaques and tangles occur in visual processing brain regions prior to their occurrence in the hippocampus [65]. Thus visual disturbance in $A D$ may precede memory impairment. Since these visual deficiencies are not specific to $A D, a$ newer field of research is investigating the hypothesis that there might be specific 
pathological changes in the eye that accompany the disease. Such ocular changes may contribute to the visual deficiencies, or be a result of damage to the visual pathways of the brain. If the eye does harbor an endophenotype of $A D$, this would give hope for an ocular diagnosis of $A D$ as well as opening up a new avenue for finding other genetic determinants of the disease. There is hope that the eye might yield biomarkers that are either highly specific for $A D$, or can contribute to an $A D$-specific risk-profile analysis in combination with genetic, cognitive and other tests. The following sections describe reported AD-associated changes to the eye.

\section{Ocular Biomarkers for Early Detection of Alzheimer's Disease}

\section{Overview}

Statistically significant ocular abnormalities that have been reported to accompany AD are tabulated below and discussed in the following sections;

(Table 1)

(Figure 1)

\section{Pupil Responses in Alzheimer's Disease}

The pupil is the aperture stop of the eye and controls the retinal illumination (see Figs. 1 and 2). The size of the pupil is regulated by the brain in response to the signals it receives from the eyes. Pupil size changes with brightness of incident light, emotions (e.g. fear), pain, cognitive tasks and with use of certain drugs (e.g. alcohol, opioids, LSD). 
(Figure 2)

Pharmacological drugs delivered in eye-drops can affect the iris muscles, causing the pupil to contract or dilate, as is often required for ophthalmological examinations. A hypersensitive pupil response to a cholinergic agonist (pilocarpine - contraction) or antagonist (tropicamide - dilation) has been reported in AD patients [69-78]. The neurotransmitter acetylcholine is deficient in the $A D$ brain $[67,79]$, hence cholinergic dysfunction in iris nerve cells is a possible explanation for the hypersensitive response, although in this case one would expect to find agonist hypersensitivity with antagonist subsensitivity, or vice versa. Alternative explanations more consistent with the dual hypersensitivity include $A D$ related damage to the locus coeruleus brain region which is involved in pupillary control [80] or increased corneal penetration of the cholinergic eyedrops. One study using a fluorescent marker to evaluate corneal penetration of tropicamide found no difference between $A D$ and controls [81], but further studies are required to confirm this result. It should also be noted that not all studies controlled for medications with anticholinergic effects.

The hypersensitive response was in some cases identified early in the disease progress, encouraging utilization for AD screening, however other studies have brought into question both the sensitivity and specificity of the test. Some studies found no significant hypersensitivity in AD [81-91], or a hypersensitive response in APOE- $\varepsilon 4$ allele carriers rather than $A D[78,92]$, affecting carriers of this allele who are cognitively normal (although at increased risk of progressing to AD). A similar hypersensitivity has been reported in Down's syndrome subjects - who develop AD as a result of an extra copy of the A $\beta P P$ gene [93], yet also in healthy young adults [87]. Still other studies have demonstrated modulation of the 
pupil dilation response by eye color [93] or age [83-84, 94]. These results have left the reliability of the pupil dilation test for $A D$ in question.

The pupil light reflex (Fig. 2) is the response of the pupil to a bright flash of light, involving rapid contraction followed by dilation back to original size. This reflex has been used as a neurological screening tool for disorders such as Parkinson's disease, Huntington's disease, schizophrenia, multiple sclerosis and trauma [95-98]. Since it is mainly a parasympathetic cholinergic response [99], the pupil light reflex could also possibly be affected if central cholinergic depletion in AD extends to the parasympathetic oculomotor system.

The pupil light reflex has been investigated as a non-invasive, ocular predictive marker for $A D$. Changes to a number of response parameters have been found in $A D$ compared to healthy ageing [100], with a single parameter (reduced "maximum constriction acceleration") facilitating perfect classification in one study. This built upon previous studies which also found statistically significant differences in pupil flash response between $A D$ and controls [91, 101-102], but Granholm et al. [91] found that AD and Parkinson's disease patients exhibited the same results. This suggests that specificity might also be an issue for this test, although "maximum constriction acceleration" was not considered in this study. The pupil flash response is also influenced by age [103]. More research is required to confirm the sensitivity and specificity of the pupil flash response parameters as a screening tool for $A D$.

\section{The Ocular Lens and Vitreous Humor in Alzheimer's Disease}

When light enters the eye it passes through the outer 'corneal' layer, followed by the aqueous humor and then the intra-ocular lens (see Fig. 1). The role of this anterior region of 
the eye is to focus an optical image of the outside world onto the retina. One disorder that can disrupt this role is cataract; an opacification of the lens often due to protein aggregation (see Fig. 3). Cataracts are a common problem in the elderly, with progressive deposition of insoluble protein in the lens and extensive oxidative damage generally caused by environmental factors such as UV exposure [104-105].

The ability of the lens to focus light is achieved by its high protein concentration, higher than any other tissue of the human body. This high protein concentration, along with the optical accessibility of the lens, makes it ideal for the optical investigation of protein aggregation in disease, in vivo. The $A \beta$ protein involved in the pathogenesis of $A D$ in the brain has also been found to exist in the lens ( $A \beta 40$ and $A \beta 42)$, aqueous humor $(A \beta 40)$ and vitreous humor $(A \beta 42)$ of the normal human eye [106-107].

(Figure 3)

Remarkably, research indicates that a particular type of cataract (equatorial supranuclear cataract) might be specific to AD sufferers [106]. Slit-lamp microscopy of ex-vivo intra-ocular lenses of individuals with $A D$ consistently revealed equatorial supranuclear cataracts. Subsequent histochemical analysis in the same study indicated that $A \beta$ aggregates are present in the cytosol of the lens fiber cells co-localizing with the cataracts. This cataract has also been reported in Down's syndrome subjects [108] - who develop AD as a result of an extra copy of the AßPP gene.

These cataracts (or the initial $A \beta$ aggregation in the lens) could thus be a biomarker for $A D$, although it is unknown at which stage of $A D$ pathogenesis they occur. The location of the AD cataract is at the equatorial periphery of the lens posterior to the iris. The anatomical relationship of the lens relative to the iris renders AD-linked supranuclear opacification 
virtually harmless with respect to visual impairment and difficult to detect on routine physical examination. However, these AD-linked lesions are readily observed by slit lamp ophthalmological evaluation in fully dilated subjects. If $A \beta$ is indeed aggregating in the $A D$ lens, leading to these cataracts, it is possible that the initial molecular changes could be detected non-invasively as an early screening or diagnostic test. Further research is needed to establish the specificity of these cataracts and lens $A \beta$ aggregations to $A D$, since both $A \beta P P$ and $A \beta$ have been shown to increase in concentration in the normal mammalian lens in response to UV radiation or other oxidative effects [109].

For early diagnosis of $A D$, it has been proposed that a suitable eye-drop biomarker may enable $A \beta$ in the anterior chamber to be stained and quantified [106]. Alternatively, the size of $A \beta$ aggregates in the eye may facilitate non-invasive detection with optical scattering [110], spectral or autofluorescence techniques. Dynamic light scattering (DLS) uses backscatter from a low energy laser beam to determine information about particle size, shape, movement and interactions. The technique is applicable to all eye tissues and has already shown promise for early cataract detection by monitoring the $\alpha$-crystallin proteins that prevent protein aggregation in the lens [111-113].

Raman spectroscopy and AF techniques both involve illumination of the sample at a specific wavelength followed by measurement of the in-elastically scattered light at different wavelengths. Raman spectroscopy with principal components analysis has been used to distinguish $A D$ from control ex vivo post-mortem brain tissues, based on spectra of protein aggregates [114-117]. AD brain tissues also exhibit visual and infrared-excited AF [116, 118]. These techniques could prove useful for non-invasive, early diagnosis of AD using the eye. The eye contains three main fluid chambers called the anterior, posterior and vitreous chambers. The aqueous humor fills the anterior and posterior chambers (see Fig. 1), 
providing nutrients to the lens and cornea and maintaining the convex curvature of the cornea. The vitreous humor has functional interactions with the lens and retina. No changes in these chambers have been reported in $A D$ to date, but a change in $A \beta 42$ and tau protein levels in the vitreous humor has been linked to retinal diseases such as diabetic retinopathy and "glaucoma concurrent with other ocular diseases" [107]. This change in protein levels is similar to that observed in the CSF in AD. Given the retinal degeneration observed in $A D$ [119-123] and the recently reported common features between AD and glaucoma [61, 107, 121-130], the vitreous humor is an interesting focus for future research into ocular protein changes in AD.

\section{The Retina and Optic Disc in Alzheimer's Disease}

While the role of the anterior eye is to focus light onto the retina, the retina's task is to convert the light into electrical signals that enter the brain. The retina consists of multiple layers of neural and photoreceptor cells, along with nerve fibers and vasculature (see Figs. 4-6). The optic disc (or optic nerve head) is the interface between the retina and the optic nerve and is the location at which blood vessels and retinal nerve fibers leave the retina. Reduced visual performance in $A D$ may be the result of pathology in the visual centers of the brain, but it also remains a possibility that retinal degeneration is involved, perhaps as a consequence of visual centre damage.

Ocular morphology reported in AD includes changes to the retinal vasculature and optic disc, retinal cell loss and thinning of the retinal nerve fiber layer (RNFL). A recent study by 
Berisha et al. found that AD participants had a specific pattern of RNFL loss (measured by optical coherence tomography, OCT), narrower venules and decreased blood flow in these venules (both measured by a laser Doppler instrument) [120]. A limitation of the study was the small participant numbers ( 9 probable AD and 8 controls). It should also be noted that retinal vessel widths are influenced by age and race and can be altered in many disorders [131]. Decreased retinal venular caliber (vessel diameter), as reported in $A D$, has otherwise only been associated with high current blood pressure and low high-density lipoprotein (HDL) cholesterol levels [131]. In contrast, increased retinal venular caliber is associated with hyperglycaemia, obesity and inflammation [131].

(Figure 4)

If retinal vascular constriction is associated with $A D$, it is unclear whether the reduced blood flow might be responsible for the reported retinal cell death or instead might be a response to the associated reduction in metabolic demand. $A \beta$ has been reported to exhibit a constrictive effect on cerebral vessels [10] but it is unclear whether $A \beta$ levels are increased in the $A D$ retina. Plaques and tangles have not been found in the human retina although $A \beta$ has been isolated in aged human retinas [132]. Research on the retinas of AD transgenic mice has demonstrated $A \beta$ plaques, hyperphosphorylated tau, increased microvascular deposition of $A \beta$ and neuroinflammation [133-134]. $A \beta$ immunotherapy in such transgenic mice has resulted in the clearance of retinal plaques but an increase in retinal amyloid angiopathy, identifying non-invasive retinal imaging as an alternative method for monitoring disease response to immunotherapy in these mice.

In addition to retinal venular constriction in human $A D$, Berisha et al. demonstrated significant thinning of the superior RNFL using optical coherence tomography (OCT, see Figs. 
5 and 6). This region corresponds with the inferior visual field and these changes could explain the vision loss reported in this area in AD [48]. Other OCT studies have reported different patterns of RNFL loss (general, parapapillary and macular) [119, 135-136]. Iseri et al. found macular thinning in AD to be related to the severity of cognitive impairment [136]. Parisi et al. found RNFL thinning to be related to retinal dysfunction as revealed by abnormal pattern electroretinogram (PERG) responses [135]. Other studies have also found abnormal PERG responses in AD [137-138].

(Figure 5)

(Figure 6)

The loss of RNFL thickness in AD is linked to a depletion of retinal ganglion cells (RGC) and optic nerve axons as identified by histopathological studies [61, 139-143]. RGCs are the final common pathway that transfer visual information through the retinal nerve fibres and then the optic nerve into the brain (Fig. 7). A postmortem study by Blanks et al. [141] demonstrated a $25 \%$ decrease in RGC at the level of the foveal and parafoveal retina, while other studies have found no significant changes [144-145]. Further research is needed to confirm the RGC loss in $A D$, to establish any connection with $A \beta$ in the retina and to confirm whether RGC loss is a cause of visual impairment in AD.

(Figure 7)

Retinal photography (Fig. 4) has also been used to identify RNFL abnormalities (nerve fiber loss) in $A D$ [121-122], although one study indicated practical difficulties in using this approach for $A D$ screening. The retinal nerve fibers are thick enough in the inner retina to make them visible in retinal photographs (Fig. 4), hence revealing areas of RNFL loss. While 
Berisha et al. found reduced venular caliber in $A D$ using a laser Doppler device, no retinal photography study has yet confirmed any retinal vascular changes in $A D$, possibly because such measurements using photography are complicated by issues of calibration and vessel boundary identification. Nevertheless, retinal photography does have the potential to detect RNFL and retinal vascular changes and hence needs to be pursued further in AD screening research.

$A D$ is known to have a vascular component, with small-vessel disease, microinfarction and cerebral amyloid angiopathy (characterised by $A \beta$ deposition in vessel walls) [146-147]. A $\beta$ plaques as well as retinal microvascular deposition of $A \beta$ have been identified in the retinas of AD transgenic mouse models [133] and could possibly be detected by non-invasive optical scattering [110], Raman spectroscopic or fluorescent tagging techniques. Given the homology between the retinal and cerebral microvasculatures [148], it is not unexpected that changes in the retinal vasculature might also occur in AD. Vascular topography, including the angles at which blood vessels bifurcate and the relationship between the widths of parent to daughter blood vessels at vascular junctions is optimized in healthy subjects in order to minimize shear stress across a vascular network [149-150]. Variations from the optimal geometrical topography are known to occur in particular vascular conditions [151-152]. Similar variations may occur in AD due to the disease's vascular component and hence are worthy of being explored with retinal photography.

Retinal photography and Scanning Laser Ophthalmoscopy (SLO) have both been used to demonstrate optic disc changes in $A D$, including optic disc pallor, pathologic disc cupping (hollowing-out), and thinning of the neuro-retinal rim [122-123]. Some of the ocular morphologies found in AD are also found in the eye disease glaucoma, specifically RNFL thinning, optic disc cupping and visual field loss. Glaucoma is second only to cataract as a 
leading cause of blindness worldwide [153] and has ocular hypertension as its largest risk factor. The 5-fold higher chance of visual field defects and/or optic disc cupping found in AD has been interpreted as a higher occurrence rate of glaucoma in AD [124]. However, in this study, no AD participants had a family history of glaucoma, and ocular hypertension was not found in AD participants but was found in $7.5 \%$ of controls, reducing the likelihood that open-angle glaucoma was the cause. This is still in question though, with another study supporting the increased incidence of open-angle glaucoma in AD [154].

A greater than 10\%/year decay in visual field and optic disc cupping were demonstrated in glaucoma patients who were later diagnosed with $A D$, whereas an average $3 \% / y e a r$ decay in visual field was observed in glaucoma patients who did not develop $A D$, indicating that $A D$ accelerates the progression of glaucoma symptoms [126]. However, increased rates of visual field defects and/or optic disc cupping have also been reported in Parkinson's disease [125] and since these changes are observed in the common eye disease glaucoma, they are unlikely to provide a test that has specificity for AD.

However, it is possible that investigations into these retinal changes in $A D$ and glaucoma might yield interesting results about the pathogenesis of the diseases, as well as their treatment and monitoring. The similarities between the ocular effects of $A D$ and glaucoma extend to changes observed in PERG recordings [127], the type of cells lost (large magnocellular RGC [61]) and possibly to the mechanism of RGC loss (apoptosis) [128-129]. In experimental glaucoma, $A \beta$ co-localizes with RGC apoptosis and induces RGC apoptosis in vivo [130]. In addition, targeting the $A \beta$ pathway with a $\beta$-secretase inhibitor, Congo red or $A \beta$-antibody has been found to be effective in treating experimental glaucoma (reducing RGC apoptosis) [130]. 
Chronic ocular hypertension (elevated intra-ocular pressure - IOP) has long been assumed to be a cause of RGC loss in glaucoma and has been shown to increase $A \beta$ production in the rat retina [128]. Interestingly, in addition to its neuroprotective effects, a cholinesterase inhibitor used to treat $A D$ has demonstrated dual therapeutic potential by reducing IOP in AD patients [155]. Current treatments for glaucoma are directed at reducing IOP, but evidence indicates that RGC loss still occurs in many glaucoma patients after successful IOP normalization, indicating that other mechanisms are involved.

In addition to glaucoma, $A \beta$ has also been implicated in other retinal diseases such as agerelated macular degeneration (AMD) [156-159]. This provides hope that these common neurodegenerative diseases (AD, Glaucoma and AMD) could be targeted simultaneously for treatment and monitoring, but reduces the likelihood of an A $\beta$-based, AD-specific biomarker in the retina. If $A \beta$ changes in the retina are to be useful for $A D$ screening, significant differences from the changes observed in retinal diseases must be identified. A $\beta$ plaques as well as retinal microvascular deposition of $A \beta$ have been identified in the retinas of $A D$ transgenic mouse models [133]. If such changes occur in human $A D$, they could possibly be detected by non-invasive optical scattering [110], Raman spectroscopic or fluorescent tagging techniques. $A D$ brain tissues exhibit visual and infrared excited auto-fluorescence (AF) [118]. Retinal AF changes are observed in a number of eye disorders including glaucoma, in which lipofuscin accumulation in parapapillary retinal pigment epithelial (RPE) cells causes AF changes [160]. Given the similarity of the retinal cell death process reported in glaucoma and AD [128-129], AF changes are also worthy of being investigated in the AD retina. It is hoped that these techniques could prove useful for non-invasive, early diagnosis of $A D$ using the eye. 


\section{Conclusions}

The terrible impact of $A D$, both on those directly affected and on society in general, creates a pressing need for better treatments. By the time a person is diagnosed with "probable AD" using current techniques, significant irreversible neuronal degeneration has already occurred. Therefore, research into better treatments must be paralleled by research into technologies to screen populations for $A D$, to identify cases before cognitive symptoms arise.

Ocular morphologies reported in $A D$ give hope for a non-invasive, cost-effective screening test for AD. Evidence is accumulating in support of AD-related changes in the eye, but finding a sufficiently sensitive and specific ocular biomarker is proving to be a major challenge. Many reported ocular changes in AD also occur in other disorders. Optic disc changes, visual field defects and RNFL/retinal cell loss are also observed in the eye disease glaucoma. Retinal vessel widths are influenced by age and race and can be altered in many disorders. Similarly, pupil responses are influenced by age and eye color and are altered in many neurological disorders. Also, most studies into ocular morphology in AD have been limited by small participant numbers, few study groups and little relevant medical information on participants. Hence larger studies are required to confirm and investigate further these ocular changes in AD.

There is no doubt that the substantial diagnostic error rate in $A D$ is confounding many aspects of $A D$ research. A combination of new brain imaging techniques and CSF biomarkers has the potential to alleviate this problem, leading to more robust results in AD research, including ocular morphology. No studies have yet compared ocular morphology in AD to brain A $\beta$-loading or CSF protein changes, an approach that has the potential to shed light on 
connections between ocular changes and AD. There are also many more ocular parameters left to investigate in AD.

Thus there remains scope for ocular changes to be utilised in AD screening or diagnostic purposes with greater sensitivity and specificity and at an earlier stage in the disease process. An ocular screening test for AD would benefit $A D$ sufferers and researchers and possibly provide new insight into the molecular processes and genetic determinants of the disease. An ocular biomarker or biomarkers could turn out to be highly specific for AD, or to be a useful component in a multidisciplinary approach aimed at producing an earlier and more accurate diagnosis of Alzheimer's disease.

\section{Bibliography}

[1] Brookmeyer R, Johnson E, Ziegler-Graham K, Arrighi HM (2007) Forecasting the global burden of Alzheimer's disease. Alzheimer's and Dementia 3, 186-191.

[2] Brookmeyer R, Gray S, Kawas C (1998) Projections of Alzheimer's disease in the United States and the public health impact of delaying disease onset. Am J Public Health 88, 1337-1342.

[3] Petersen RC, Stevens JC, Ganguli M, Tangalos EG, Cummings JL, DeKosky ST (2001) Practice parameter: Early detection of dementia: Mild cognitive impairment (an evidence-based review): Report of the Quality Standards Subcommittee of the American Academy of Neurology. Neurology 56, 1133-1142.

[4] Tiraboschi P, Hansen LA, Thal L, Corey-Bloom J (2004) The importance of neuritic plaques and tangles to the development and evolution of AD. Neurology 62, 19841989.

[5] Bates KA, Sohrabi HR, Rodrigues M, Beilby J, Dhaliwal SS, Taddei K, Criddle A, Wraith M, Howard M, Martins G, Paton A, Mehta P, Foster JK, Martins IJ, Lautenschlager NT, Mastaglia FL, Laws SM, Gandy SE, Martins RN (2009) Association of cardiovascular factors and Alzheimer's disease plasma amyloid-beta protein in subjective memory complainers. J Alzheimers Dis 17, 305-318.

[6] Shankar GM, Li S, Mehta TH, Garcia-Munoz A, Shepardson NE, Smith I, Brett FM, Farrell MA, Rowan MJ, Lemere CA, Regan CM, Walsh DM, Sabatini BL, Selkoe DJ 
(2008) Amyloid-beta protein dimers isolated directly from Alzheimer's brains impair synaptic plasticity and memory. Nat Med 14, 837-842.

[7] Xu F, Davis J, Miao J, Previti ML, Romanov G, Ziegler K, Van Nostrand WE (2005) Protease nexin-2/amyloid beta-protein precursor limits cerebral thrombosis. Proc Natl Acad Sci U S A 102, 18135-18140.

[8] Turner PR, O'Connor K, Tate WP, Abraham WC (2003) Roles of amyloid precursor protein and its fragments in regulating neural activity, plasticity and memory. Prog Neurobiol 70, 1-32.

[9] Kang J, Lemaire HG, Unterbeck A, Salbaum JM, Masters CL, Grzeschik KH, Multhaup G, Beyreuther K, Muller-Hill B (1987) The precursor of Alzheimer's disease amyloid A4 protein resembles a cell-surface receptor. Nature 325, 733-736.

[10] Suo Z, Humphrey J, Kundtz A, Sethi F, Placzek A, Crawford F, Mullan M (1998) Soluble Alzheimers beta-amyloid constricts the cerebral vasculature in vivo. Neurosci Lett 257, 77-80.

[11] Chan C-W, Dharmarajan A, Atwood CS, Huang X, Tanzi RE, Bush Al, Martins RN (1999) Anti-apoptotic action of Alzheimer ABeta. ALZHEIMERS REPORTS 2, 113-119.

[12] Hardy J, Cullen K (2006) Amyloid at the blood vessel wall. Nat Med 12, 756-757.

[13] Soscia SJ, Kirby JE, Washicosky KJ, Tucker SM, Ingelsson M, Hyman B, Burton MA, Goldstein LE, Duong S, Tanzi RE, Moir RD (2010) The Alzheimer's disease-associated amyloid beta-protein is an antimicrobial peptide. PLoS One 5, e9505.

[14] Butterfield DA, Lauderback CM (2002) Lipid peroxidation and protein oxidation in Alzheimer's disease brain: potential causes and consequences involving amyloid beta-peptide-associated free radical oxidative stress. Free Radic Biol Med 32, 10501060.

[15] Lue LF, Kuo YM, Roher AE, Brachova L, Shen Y, Sue L, Beach T, Kurth JH, Rydel RE, Rogers J (1999) Soluble amyloid beta peptide concentration as a predictor of synaptic change in Alzheimer's disease. Am J Pathol 155, 853-862.

[16] Tanzi RE, Bertram L (2001) New frontiers in Alzheimer's disease genetics. Neuron 32, 181-184.

[17] Yin Yl, Bassit B, Zhu L, Yang X, Wang C, Li YM (2007) \{gamma\}-Secretase Substrate Concentration Modulates the Abeta42/Abeta40 Ratio: IMPLICATIONS FOR ALZHEIMER DISEASE. J Biol Chem 282, 23639-23644.

[18] Ramsden M, Kotilinek L, Forster C, Paulson J, McGowan E, SantaCruz K, Guimaraes A, Yue M, Lewis J, Carlson G, Hutton M, Ashe KH (2005) Age-dependent neurofibrillary tangle formation, neuron loss, and memory impairment in a mouse model of human tauopathy (P301L). J Neurosci 25, 10637-10647.

[19] Santacruz K, Lewis J, Spires T, Paulson J, Kotilinek L, Ingelsson M, Guimaraes A, DeTure M, Ramsden M, McGowan E, Forster C, Yue M, Orne J, Janus C, Mariash A, Kuskowski M, Hyman B, Hutton M, Ashe KH (2005) Tau suppression in a neurodegenerative mouse model improves memory function. Science 309, 476-481.

[20] Spires TL, Orne JD, SantaCruz K, Pitstick R, Carlson GA, Ashe KH, Hyman BT (2006) Region-specific dissociation of neuronal loss and neurofibrillary pathology in a mouse model of tauopathy. Am J Pathol 168, 1598-1607.

[21] Bush Al (2002) Metal complexing agents as therapies for Alzheimer's disease. Neurobiol Aging 23, 1031-1038.

[22] Bush Al (2003) The metallobiology of Alzheimer's disease. Trends Neurosci 26, 207214. 
[23] Schenk D, Barbour R, Dunn W, Gordon G, Grajeda H, Guido T, Hu K, Huang J, Johnson-Wood K, Khan K, Kholodenko D, Lee M, Liao Z, Lieberburg I, Motter R, Mutter L, Soriano F, Shopp G, Vasquez N, Vandevert C, Walker S, Wogulis M, Yednock T, Games D, Seubert P (1999) Immunization with amyloid-beta attenuates Alzheimer-disease-like pathology in the PDAPP mouse. Nature 400, 173-177.

[24] Parker MH, Chen R, Conway KA, Lee DH, Luo C, Boyd RE, Nortey SO, Ross TM, Scott $M K$, Reitz AB (2002) Synthesis of (-)-5,8-dihydroxy-3R-methyl-2R-(dipropylamino)1,2,3,4-tetrahydronaphthale ne: an inhibitor of beta-amyloid(1-42) aggregation. Bioorg Med Chem 10, 3565-3569.

[25] Doody RS, Gavrilova SI, Sano M, Thomas RG, Aisen PS, Bachurin SO, Seely L, Hung D (2008) Effect of dimebon on cognition, activities of daily living, behaviour, and global function in patients with mild-to-moderate Alzheimer's disease: a randomised, double-blind, placebo-controlled study. Lancet 372, 207-215.

[26] Medivation, Press release 3 March 2010. Pfizer and Medivation announce results from two Phase 3 studies in Dimebon (latrepirdine*) Medivation website [online], http://investors.medivation.com/releasedetail.cfm?ReleaselD=448818, Accessed June 2010.

[27] Lazarov O, Robinson J, Tang YP, Hairston IS, Korade-Mirnics Z, Lee VM, Hersh LB, Sapolsky RM, Mirnics K, Sisodia SS (2005) Environmental enrichment reduces Abeta levels and amyloid deposition in transgenic mice. Cell 120, 701-713.

[28] Wilson RS, Mendes De Leon CF, Barnes LL, Schneider JA, Bienias JL, Evans DA, Bennett DA (2002) Participation in cognitively stimulating activities and risk of incident Alzheimer disease. JAMA 287, 742-748.

[29] Cirrito JR, Yamada KA, Finn MB, Sloviter RS, Bales KR, May PC, Schoepp DD, Paul SM, Mennerick S, Holtzman DM (2005) Synaptic activity regulates interstitial fluid amyloid-beta levels in vivo. Neuron 48, 913-922.

[30] Buckner RL, Snyder AZ, Shannon BJ, LaRossa G, Sachs R, Fotenos AF, Sheline YI, Klunk WE, Mathis CA, Morris JC, Mintun MA (2005) Molecular, structural, and functional characterization of Alzheimer's disease: evidence for a relationship between default activity, amyloid, and memory. J Neurosci 25, 7709-7717.

[31] Schaffer C, Donlon P (1983) Medical causes of psychiatric symptoms in the eldery. Clinical Gerontologist 1, 3-18.

[32] Thal LJ, Kantarci K, Reiman EM, Klunk WE, Weiner MW, Zetterberg H, Galasko D, Pratico D, Griffin S, Schenk D, Siemers E (2006) The role of biomarkers in clinical trials for Alzheimer disease. Alzheimer Dis Assoc Disord 20, 6-15.

[33] Sunderland T, Linker G, Mirza N, Putnam KT, Friedman DL, Kimmel LH, Bergeson J, Manetti GJ, Zimmermann M, Tang B, Bartko JJ, Cohen RM (2003) Decreased betaamyloid1-42 and increased tau levels in cerebrospinal fluid of patients with Alzheimer disease. JAMA 289, 2094-2103.

[34] Fagan AM, Mintun MA, Mach RH, Lee SY, Dence CS, Shah AR, LaRossa GN, Spinner ML, Klunk WE, Mathis CA, DeKosky ST, Morris JC, Holtzman DM (2006) Inverse relation between in vivo amyloid imaging load and cerebrospinal fluid Abeta42 in humans. Ann Neurol 59, 512-519.

[35] Rowe CC, Ng S, Ackermann U, Gong SJ, Pike K, Savage G, Cowie TF, Dickinson KL, Maruff P, Darby D, Smith C, Woodward M, Merory J, Tochon-Danguy H, O'Keefe G, Klunk WE, Mathis CA, Price JC, Masters CL, Villemagne VL (2007) Imaging betaamyloid burden in aging and dementia. Neurology 68, 1718-1725. 
[36] Morris JC, Roe CM, Grant EA, Head D, Storandt M, Goate AM, Fagan AM, Holtzman DM, Mintun MA (2009) Pittsburgh Compound B Imaging and Prediction of Progression From Cognitive Normality to Symptomatic Alzheimer Disease. Arch Neurol 66, 1469-1475.

[37] Selkoe DJ (2001) Alzheimer's disease: genes, proteins, and therapy. Physiol Rev 81, 741-766.

[38] Bu G (2009) Apolipoprotein E and its receptors in Alzheimer's disease: pathways, pathogenesis and therapy. Nat Rev Neurosci 10, 333-344.

[39] Corder EH, Saunders AM, Strittmatter WJ, Schmechel DE, Gaskell PC, Small GW, Roses AD, Haines JL, Pericak-Vance MA (1993) Gene dose of apolipoprotein E type 4 allele and the risk of Alzheimer's disease in late onset families. Science 261, 921-923.

[40] Harold D, Abraham R, Hollingworth P, Sims R, Gerrish A, Hamshere ML, Pahwa JS, Moskvina V, Dowzell K, Williams A, Jones N, Thomas C, Stretton A, Morgan AR, Lovestone S, Powell J, Proitsi P, Lupton MK, Brayne C, Rubinsztein DC, Gill M, Lawlor B, Lynch A, Morgan K, Brown KS, Passmore PA, Craig D, McGuinness B, Todd S, Holmes C, Mann D, Smith AD, Love S, Kehoe PG, Hardy J, Mead S, Fox N, Rossor M, Collinge J, Maier W, Jessen F, Schurmann B, van den Bussche H, Heuser I, Kornhuber J, Wiltfang J, Dichgans M, Frolich L, Hampel H, Hull M, Rujescu D, Goate AM, Kauwe JS, Cruchaga C, Nowotny P, Morris JC, Mayo K, Sleegers K, Bettens K, Engelborghs S, De Deyn PP, Van Broeckhoven C, Livingston G, Bass NJ, Gurling H, McQuillin A, Gwilliam R, Deloukas P, Al-Chalabi A, Shaw CE, Tsolaki M, Singleton AB, Guerreiro R, Muhleisen TW, Nothen MM, Moebus S, Jockel KH, Klopp N, Wichmann HE, Carrasquillo MM, Pankratz VS, Younkin SG, Holmans PA, O'Donovan M, Owen MJ, Williams J (2009) Genome-wide association study identifies variants at CLU and PICALM associated with Alzheimer's disease. Nat Genet 41, 1088-1093.

[41] Lambert JC, Heath S, Even G, Campion D, Sleegers K, Hiltunen M, Combarros O, Zelenika D, Bullido MJ, Tavernier B, Letenneur L, Bettens K, Berr C, Pasquier F, Fievet N, Barberger-Gateau P, Engelborghs S, De Deyn P, Mateo I, Franck A, Helisalmi S, Porcellini E, Hanon O, de Pancorbo MM, Lendon C, Dufouil C, Jaillard C, Leveillard T, Alvarez V, Bosco P, Mancuso M, Panza F, Nacmias B, Bossu P, Piccardi P, Annoni G, Seripa D, Galimberti D, Hannequin D, Licastro F, Soininen $H$, Ritchie K, Blanche $H$, Dartigues JF, Tzourio C, Gut I, Van Broeckhoven C, Alperovitch A, Lathrop M, Amouyel P (2009) Genome-wide association study identifies variants at CLU and CR1 associated with Alzheimer's disease. Nat Genet 41, 1094-1099.

[42] Bertram L, Tanzi RE (2008) Thirty years of Alzheimer's disease genetics: the implications of systematic meta-analyses. Nat Rev Neurosci 9, 768-778.

[43] Villemagne VL, Pike KE, Darby D, Maruff P, Savage G, Ng S, Ackermann U, Cowie TF, Currie J, Chan SG, Jones G, Tochon-Danguy H, O'Keefe G, Masters CL, Rowe CC (2008) Abeta deposits in older non-demented individuals with cognitive decline are indicative of preclinical Alzheimer's disease. Neuropsychologia 46, 1688-1697.

[44] Pike KE, Savage G, Villemagne VL, Ng S, Moss SA, Maruff P, Mathis CA, Klunk WE, Masters CL, Rowe CC (2007) Beta-amyloid imaging and memory in non-demented individuals: evidence for preclinical Alzheimer's disease. Brain 130, 2837-2844.

[45] Simonsen AH, McGuire J, Podust VN, Davies H, Minthon L, Skoog I, Andreasen N, Wallin A, Waldemar G, Blennow K (2008) Identification of a novel panel of cerebrospinal fluid biomarkers for Alzheimer's disease. Neurobiol Aging 29, 961-968. 
[46] Katz B, Rimmer S (1989) Ophthalmologic manifestations of Alzheimer's disease. Surv Ophthalmol 34, 31-43.

[47] Sadun AA, Borchert M, DeVita E, Hinton DR, Bassi CJ (1987) Assessment of visual impairment in patients with Alzheimer's disease. Am J Ophthalmol 104, 113-120.

[48] Trick GL, Trick LR, Morris P, Wolf M (1995) Visual field loss in senile dementia of the Alzheimer's type. Neurology 45, 68-74.

[49] Whittaker KW, Burdon MA, Shah P (2002) Visual field loss and Alzheimer's disease. Eye (Lond) 16, 206-208.

[50] Pache M, Smeets CH, Gasio PF, Savaskan E, Flammer J, Wirz-Justice A, Kaiser HJ (2003) Colour vision deficiencies in Alzheimer's disease. Age Ageing 32, 422-426.

[51] Cogan DG (1987) Alzheimer syndromes. Am J Ophthalmol 104, 183-184.

[52] Cronin-Golomb A, Sugiura R, Corkin S, Growdon JH (1993) Incomplete achromatopsia in alzheimer's disease. Neurobiology of Aging 14, 471-477.

[53] Lakshminarayanan V, Lagrave J, Kean ML, Dick M, Shankle R (1996) Vision in dementia: contrast effects. Neurol Res 18, 9-15.

[54] Crow RW, Levin LB, LaBree L, Rubin R, Feldon SE (2003) Sweep visual evoked potential evaluation of contrast sensitivity in Alzheimer's dementia. Invest Ophthalmol Vis Sci 44, 875-878.

[55] Nissen MJ, Corkin S, Buonanno FS, Growdon JH, Wray SH, Bauer J (1985) Spatial vision in Alzheimer's disease. General findings and a case report. Arch Neurol 42, 667-671.

[56] Mendola JD, Cronin-Golomb A, Corkin S, Growdon JH (1995) Prevalence of visual deficits in Alzheimer's disease. Optom Vis Sci 72, 155-167.

[57] Schlotterer G, Moscovitch M, Crapper-McLachlan D (1984) Visual processing deficits as assessed by spatial frequency contrast sensitivity and backward masking in normal ageing and Alzheimer's disease. Brain 107 ( Pt 1), 309-325.

[58] Mielke R, Kessler J, Fink G, Herholz K, Heiss WD (1995) Dysfunction of visual cortex contributes to disturbed processing of visual information in Alzheimer's disease. Int $J$ Neurosci 82, 1-9.

[59] Morrison JH, Hof PR, Bouras C (1991) An anatomic substrate for visual disconnection in Alzheimer's disease. Ann N Y Acad Sci 640, 36-43.

[60] Gilmore GC, Wenk HE, Naylor LA, Koss E (1994) Motion Perception and Alzheimer's Disease. Journal of Gerontology 49, P52-P57.

[61] Sadun AA, Bassi CJ (1990) Optic nerve damage in Alzheimer's disease. Ophthalmology 97, 9-17.

[62] Fletcher WA, Sharpe JA (1988) Smooth pursuit dysfunction in Alzheimer's disease. Neurology 38, 272-277.

[63] Mendez MF, Tomsak RL, Remler B (1990) Disorders of the visual system in Alzheimer's disease. J Clin Neuroophthalmol 10, 62-69.

[64] Leuba G (1995) Pathology of subcortical visual centres in relation to cortical degeneration in Alzheimer's disease. Neuropathology and applied neurobiology 21, 410.

[65] McKee AC, Au R, Cabral HJ, Kowall NW, Seshadri S, Kubilus CA, Drake J, Wolf PA (2006) Visual association pathology in preclinical Alzheimer disease. J Neuropathol Exp Neurol 65, 621-630.

[66] Bentley P, Driver J, Dolan RJ (2008) Cholinesterase inhibition modulates visual and attentional brain responses in Alzheimer's disease and health. Brain 131, 409-424. 
[67] Herholz K, Weisenbach S, Zundorf G, Lenz O, Schroder H, Bauer B, Kalbe E, Heiss WD (2004) In vivo study of acetylcholine esterase in basal forebrain, amygdala, and cortex in mild to moderate Alzheimer disease. Neuroimage 21, 136-143.

[68] Nobili L, Sannita WG (1997) Cholinergic modulation, visual function and Alzheimer's dementia. Vision Res 37, 3559-3571.

[69] Scinto LF, Daffner KR, Dressler D, Ransil BI, Rentz D, Weintraub S, Mesulam M, Potter $H$ (1994) A potential noninvasive neurobiological test for Alzheimer's disease. Science 266, 1051-1054.

[70] Idiaquez J, Alvarez G, Villagra R, San Martin RA (1994) Cholinergic supersensitivity of the iris in Alzheimer's disease. J Neurol Neurosurg Psychiatry 57, 1544-1545.

[71] Pomara N, Sitaram N (1995) Detecting Alzheimer's disease. Science 267, 1579-1580; author reply 1580-1571.

[72] lijima A, Haida M, Ishikawa N, Ueno A, Minamitani H, Shinohara Y (2003) Reevaluation of tropicamide in the pupillary response test for Alzheimer's disease. Neurobiol Aging 24, 789-796.

[73] Gomez-Tortosa E, del Barrio A, Jimenez-Alfaro I (1996) Pupil response to tropicamide in Alzheimer's disease and other neurodegenerative disorders. Acta Neurol Scand 94, 104-109.

[74] Grunberger J, Linzmayer L, Walter H, Rainer M, Masching A, Pezawas L, SaletuZyhlarz G, Stohr H, Grunberger M (1999) Receptor test (pupillary dilatation after application of $0.01 \%$ tropicamide solution) and determination of central nervous activation (Fourier analysis of pupillary oscillations) in patients with Alzheimer's disease. Neuropsychobiology 40, 40-46.

[75] Kalman J, Kanka A, Magloczky E, Szoke A, Jardanhazy T, Janka Z (1997) Increased mydriatic response to tropicamide is a sign of cholinergic hypersensitivity but not specific to late-onset sporadic type of Alzheimer's dementia. Biol Psychiatry 41, 909911.

[76] Robles A, Tourino R, Sesar A, Suarez P, Noya M (1996) [Experience with pupil tropicamide test in Alzheimer's disease]. Rev Neurol 24, 65-68.

[77] Kono K, Miyao M, Ishihara S, Takagi A, Ikari H, Suzuki Y, Iguchi A (1996) [Hypersensitivity in the pupil dilation response to a cholinergic antagonist in patients with Alzheimer's disease and Down's syndrome]. Nippon Ronen Igakkai Zasshi 33, 829-834.

[78] Arai H, Terajima M, Nakagawa T, Higuchi S, Mochizuki H, Sasaki H (1996) Pupil dilatation assay by tropicamide is modulated by apolipoprotein E epsilon 4 allele dosage in Alzheimer's disease. Neuroreport 7, 918-920.

[79] Tohgi H, Abe T, Hashiguchi K, Saheki M, Takahashi S (1994) Remarkable reduction in acetylcholine concentration in the cerebrospinal fluid from patients with Alzheimer type dementia. Neurosci Lett 177, 139-142.

[80] Hou RH, Samuels ER, Raisi M, Langley RW, Szabadi E, Bradshaw CM (2006) Why patients with Alzheimer's disease may show increased sensitivity to tropicamide eye drops: role of locus coeruleus. Psychopharmacology (Berl) 184, 95-106.

[81] FitzSimon JS, Waring SC, Kokmen E, McLaren JW, Brubaker RF (1997) Response of the pupil to tropicamide is not a reliable test for Alzheimer disease. Arch Neurol 54, 155-159.

[82] Kardon RH (1998) Drop the Alzheimer's drop test. Neurology 50, 588-591. 
[83] Caputo L, Casartelli M, Perrone C, Santori M, Annoni G, Vergani C (1998) The 'eye test' in recognition of late-onset Alzheimer's disease. Arch Gerontol Geriatr 27, 171177.

[84] Fridh M, Havelius U, Elofsson G, Hindfelt B (1996) The pupillary response to tropicamide in Alzheimer's disease. Acta Ophthalmol Scand 74, 276-279.

[85] Growdon JH, Graefe K, Tennis M, Hayden D, Schoenfeld D, Wray SH (1997) Pupil dilation to tropicamide is not specific for Alzheimer disease. Arch Neurol 54, 841-844.

[86] Kurz A, Marquard R, Fremke S, Leipert KP (1997) Pupil dilation response to tropicamide: a biological test for Alzheimer's disease? Pharmacopsychiatry 30, 1215.

[87] Marx JL, Kumar SR, Thach AB, Kiat-Winarko T, Frambach DA (1995) Detecting Alzheimer's disease. Science 267, 1577; author reply 1580-1571.

[88] Reitner A, Baumgartner I, Thuile C, Baradaran Dilmaghani R, Ergun E, Kaminski S, Lukas J, Dal Bianco P (1997) The mydriatic effect of tropicamide and its diagnostic use in Alzheimer's disease. Vision Res 37, 165-168.

[89] Loupe DN, Newman NJ, Green RC, Lynn MJ, KK WI, Geis TC, Edelhauser HF (1996) Pupillary response to tropicamide in patients with Alzheimer disease. Ophthalmology 103, 495-503.

[90] Treloar AJ, Assin M, Macdonald AJ (1996) Pupillary response to topical tropicamide as a marker for Alzheimer's disease. Br J Clin Pharmacol 41, 256-257.

[91] Granholm E, Morris S, Galasko D, Shults C, Rogers E, Vukov B (2003) Tropicamide effects on pupil size and pupillary light reflexes in Alzheimer's and Parkinson's disease. Int J Psychophysiol 47, 95-115.

[92] Higuchi S, Matsushita S, Hasegawa Y, Muramatsu T, Arai H, Hayashida M (1997) Apolipoprotein E epsilon 4 allele and pupillary response to tropicamide. Am J Psychiatry 154, 694-696.

[93] Sacks B, Smith S (1989) People with Down's syndrome can be distinguished on the basis of cholinergic dysfunction. J Neurol Neurosurg Psychiatry 52, 1294-1295.

[94] Higuchi S, Matsushita S, Hasegawa Y, Muramatsu T, Arai H (1997) Pupillary response to tropicamide in Japanese patients with alcoholic dementia, Alzheimer's disease, and vascular dementia. Exp Neurol 144, 199-201.

[95] Den Heijer JC, Bollen WL, Reulen JP, van Dijk JG, Kramer CG, Roos RA, Buruma OJ (1988) Autonomic nervous function in Huntington's disease. Arch Neurol 45, 309312.

[96] Meyer S, Gibb T, Jurkovich GJ (1993) Evaluation and significance of the pupillary light reflex in trauma patients. Ann Emerg Med 22, 1052-1057.

[97] Steinhauer SR, Hakerem G (1992) The pupillary response in cognitive psychophysiology and schizophrenia. Ann N Y Acad Sci 658, 182-204.

[98] Van Diemen HA, Van Dongen MM, Nauta JJ, Lanting P, Polman CH (1992) Pupillary light reflex latency in patients with multiple sclerosis. Electroencephalogr Clin Neurophysiol 82, 213-219.

[99] Loewenfeld IE (1999) The pupil: Anatomy, physiology, and clinical applications.

[100] Fotiou DF, Brozou CG, Haidich AB, Tsiptsios D, Nakou M, Kabitsi A, Giantselidis C, Fotiou $F$ (2007) Pupil reaction to light in Alzheimer's disease: evaluation of pupil size changes and mobility. Aging Clin Exp Res 19, 364-371. 
[101] Fotiou F, Fountoulakis KN, Tsolaki M, Goulas A, Palikaras A (2000) Changes in pupil reaction to light in Alzheimer's disease patients: a preliminary report. Int J Psychophysiol 37, 111-120.

[102] Prettyman R, Bitsios P, Szabadi E (1997) Altered pupillary size and darkness and light reflexes in Alzheimer's disease. J Neurol Neurosurg Psychiatry 62, 665-668.

[103] Fotiou DF, Brozou CG, Tsiptsios DJ, Fotiou A, Kabitsi A, Nakou M, Giantselidis C, Goula A (2007) Effect of age on pupillary light reflex: evaluation of pupil mobility for clinical practice and research. Electromyogr Clin Neurophysiol 47, 11-22.

[104] Hanson SR, Hasan A, Smith DL, Smith JB (2000) The major in vivo modifications of the human water-insoluble lens crystallins are disulfide bonds, deamidation, methionine oxidation and backbone cleavage. Exp Eye Res 71, 195-207.

[105] Spector A (1995) Oxidative stress-induced cataract: mechanism of action. FASEB J 9, 1173-1182.

[106] Goldstein LE, Muffat JA, Cherny RA, Moir RD, Ericsson MH, Huang X, Mavros C, Coccia JA, Faget KY, Fitch KA, Masters CL, Tanzi RE, Chylack LT, Jr., Bush Al (2003) Cytosolic beta-amyloid deposition and supranuclear cataracts in lenses from people with Alzheimer's disease. Lancet 361, 1258-1265.

[107] Yoneda S, Hara H, Hirata A, Fukushima M, Inomata Y, Tanihara H (2005) Vitreous fluid levels of beta-amyloid((1-42)) and tau in patients with retinal diseases. Jpn J Ophthalmol 49, 106-108.

[108] Moncaster JA, Pineda R, Moir RD, Lu S, Burton MA, Ghosh JG, Ericsson M, Soscia SJ, Mocofanescu A, Folkerth RD, Robb RM, Kuszak JR, Clark JI, Tanzi RE, Hunter DG, Goldstein LE (2010) Alzheimer's disease amyloid-beta links lens and brain pathology in Down syndrome. PLoS One 5, e10659.

[109] Frederikse PH, Garland D, Zigler JS, Jr., Piatigorsky J (1996) Oxidative stress increases production of beta-amyloid precursor protein and beta-amyloid (Abeta) in mammalian lenses, and Abeta has toxic effects on lens epithelial cells. J Biol Chem 271, 10169-10174.

[110] Goldstein LE, Moir R, Lu S, Fu L, Chadwick O, Arnett E, Ericsson M, Klunk W, Mathis C, Chylack LT, Jr., Clark J, Tanzi R, Moncaster JA (2006) Non-invasive early detection of beta-amyloid molecular pathology by quasi-elastic light scattering in vivo. Alzheimer's \& dementia 2, S133.

[111] Ansari RR, Datiles MB, 3rd (1999) Use of dynamic light scattering and Scheimpflug imaging for the early detection of cataracts. Diabetes Technol Ther 1, 159-168.

[112] Datiles MB, 3rd, Ansari RR, Reed GF (2002) A clinical study of the human lens with a dynamic light scattering device. Exp Eye Res 74, 93-102.

[113] Datiles MB, 3rd, Ansari RR, Suh KI, Vitale S, Reed GF, Zigler JS, Jr., Ferris FL, 3rd (2008) Clinical detection of precataractous lens protein changes using dynamic light scattering. Arch Ophthalmol 126, 1687-1693.

[114] Sudworth CD (2006) Advances in Raman spectroscopy for the diagnosis of Alzheimer's disease. Proc SPIE 6093, 139-146.

[115] Hanlon EB, Perelman LT, Vitkin El, Greco FA, McKee AC, Kowall NW (2008) Scattering differentiates Alzheimer disease in vitro. Opt Lett 33, 624-626.

[116] Hanlon EB, Itzkan I, Dasari RR, Feld MS, Ferrante RJ, McKee AC, Lathi D, Kowall NW (1999) Near-infrared fluorescence spectroscopy detects Alzheimer's disease in vitro. Photochem Photobiol 70, 236-242. 
[117] Archer JKJ, Sudworth CD, Williams R, How T, Stone N, Mann D, Black RA (2007) Improvements in Alzheimer' Disease Diagnosis using Principal Component Analysis (PCA) in Combination with Raman Spectroscopy. Proc SPIE 6628, 37.

[118] Zipfel WR, Williams RM, Christie R, Nikitin AY, Hyman BT, Webb WW (2003) Live tissue intrinsic emission microscopy using multiphoton-excited native fluorescence and second harmonic generation. Proc Natl Acad Sci U S A 100, 7075-7080.

[119] Paquet C, Boissonnot M, Roger F, Dighiero P, Gil R, Hugon J (2007) Abnormal retinal thickness in patients with mild cognitive impairment and Alzheimer's disease. Neurosci Lett 420, 97-99.

[120] Berisha F, Feke GT, Trempe CL, McMeel JW, Schepens CL (2007) Retinal abnormalities in early Alzheimer's disease. Invest Ophthalmol Vis Sci 48, 2285-2289.

[121] Hedges TR, 3rd, Perez Galves R, Speigelman D, Barbas NR, Peli E, Yardley CJ (1996) Retinal nerve fiber layer abnormalities in Alzheimer's disease. Acta Ophthalmol Scand 74, 271-275.

[122] Tsai CS (1991) Optic nerve head and nerve fiber layer in Alzheimer's disease. Archives of ophthalmology 109, 199.

[123] Danesh-Meyer HV, Birch H, Ku JY, Carroll S, Gamble G (2006) Reduction of optic nerve fibers in patients with Alzheimer disease identified by laser imaging. Neurology 67, 1852-1854.

[124] Bayer AU, Ferrari F, Erb C (2002) High Occurrence Rate of Glaucoma among Patients with Alzheimer's Disease. European Neurology 47, 165-168.

[125] Bayer AU, Keller ON, Ferrari F, Maag KP (2002) Association of glaucoma with neurodegenerative diseases with apoptotic cell death: Alzheimer's disease and Parkinson's disease. Am J Ophthalmol 133, 135-137.

[126] Bayer AU, Ferrari F (2002) Severe progression of glaucomatous optic neuropathy in patients with Alzheimer's disease. Eye 16, 209-212.

[127] Nesher R, Trick GL (1991) The pattern electroretinogram in retinal and optic nerve disease. A quantitative comparison of the pattern of visual dysfunction. Doc Ophthalmol 77, 225-235.

[128] McKinnon SJ, Lehman DM, Kerrigan-Baumrind LA, Merges CA, Pease ME, Kerrigan DF, Ransom NL, Tahzib NG, Reitsamer HA, Levkovitch-Verbin H, Quigley HA, Zack DJ (2002) Caspase activation and amyloid precursor protein cleavage in rat ocular hypertension. Invest Ophthalmol Vis Sci 43, 1077-1087.

[129] Yin H, Chen L, Chen X, Liu X (2008) Soluble amyloid beta oligomers may contribute to apoptosis of retinal ganglion cells in glaucoma. Med Hypotheses 71, 77-80.

[130] Guo L, Salt TE, Luong V, Wood N, Cheung W, Maass A, Ferrari G, Russo-Marie F, Sillito AM, Cheetham ME, Moss SE, Fitzke FW, Cordeiro MF (2007) Targeting amyloid-beta in glaucoma treatment. Proc Natl Acad Sci U S A 104, 13444-13449.

[131] Sun C, Sun (2009) Retinal Vascular Caliber: Systemic, Environmental, and Genetic Associations. Survey of Ophthalmology 54, 74.

[132] Loffler KU (1995) Immunoreactivity against tau, amyloid precursor protein, and betaamyloid in the human retina. Investigative ophthalmology \& visual science 36, 24.

[133] Liu B, Rasool S, Yang Z, Glabe CG, Schreiber SS, Ge J, Tan Z (2009) Amyloid-peptide vaccinations reduce $\{$ beta\}-amyloid plaques but exacerbate vascular deposition and inflammation in the retina of Alzheimer's transgenic mice. Am J Pathol 175, 20992110. 
[134] Perez SE, Lumayag S, Kovacs B, Mufson EJ, Xu S (2009) Beta-amyloid deposition and functional impairment in the retina of the APPswe/PS1DeltaE9 transgenic mouse model of Alzheimer's disease. Invest Ophthalmol Vis Sci 50, 793-800.

[135] Parisi V, Restuccia R, Fattapposta F, Mina C, Bucci MG, Pierelli F (2001) Morphological and functional retinal impairment in Alzheimer's disease patients. Clin Neurophysiol 112, 1860-1867.

[136] Iseri PK, Altinas O, Tokay T, Yuksel N (2006) Relationship between cognitive impairment and retinal morphological and visual functional abnormalities in Alzheimer disease. J Neuroophthalmol 26, 18-24.

[137] Katz B, Rimmer S, Iragui V, Katzman R (1989) Abnormal pattern electroretinogram in Alzheimer's disease: evidence for retinal ganglion cell degeneration? Ann Neurol 26, 221-225.

[138] Trick GL, Barris MC, Bickler-Bluth M (1989) Abnormal pattern electroretinograms in patients with senile dementia of the Alzheimer type. Ann Neurol 26, 226-231.

[139] Blanks JC, Hinton DR, Sadun AA, Miller CA (1989) Retinal ganglion cell degeneration in Alzheimer's disease. Brain Res 501, 364-372.

[140] Blanks JC, Schmidt SY, Torigoe Y, Porrello KV, Hinton DR, Blanks RH (1996) Retinal pathology in Alzheimer's disease. II. Regional neuron loss and glial changes in GCL. Neurobiol Aging 17, 385-395.

[141] Blanks JC, Torigoe Y, Hinton DR, Blanks RH (1996) Retinal pathology in Alzheimer's disease. I. Ganglion cell loss in foveal/parafoveal retina. Neurobiol Aging 17, 377-384.

[142] Hinton DR, Sadun AA, Blanks JC, Miller CA (1986) Optic-nerve degeneration in Alzheimer's disease. N Engl J Med 315, 485-487.

[143] Sadun AA, Bassi CJ (1990) The visual system in Alzheimer's disease. Res Publ Assoc Res Nerv Ment Dis 67, 331-347.

[144] Curcio CA, Drucker DN (1993) Retinal ganglion cells in Alzheimer's disease and aging. Ann Neurol 33, 248-257.

[145] Davies DC, McCoubrie P, McDonald B, Jobst KA (1995) Myelinated axon number in the optic nerve is unaffected by Alzheimer's disease. Br J Ophthalmol 79, 596-600.

[146] Ravona-Springer R, Davidson M, Noy S (2003) The role of cardiovascular risk factors in Alzheimer's disease. CNS Spectr 8, 824-833.

[147] Thal DR, Ghebremedhin E, Orantes M, Wiestler OD (2003) Vascular pathology in Alzheimer disease: correlation of cerebral amyloid angiopathy and arteriosclerosis/lipohyalinosis with cognitive decline. J Neuropathol Exp Neurol 62, 1287-1301.

[148] Patton N, Aslam T, Macgillivray T, Pattie A, Deary IJ, Dhillon B (2005) Retinal vascular image analysis as a potential screening tool for cerebrovascular disease: a rationale based on homology between cerebral and retinal microvasculatures. J Anat 206, 319-348.

[149] Zamir M, Brown N (1982) Arterial branching in various parts of the cardiovascular system. Am J Anat 163, 295-307.

[150] Zamir M, Medeiros JA (1982) Arterial branching in man and monkey. J Gen Physiol 79, 353-360.

[151] Chapman N, Dell'omo G, Sartini MS, Witt N, Hughes A, Thom S, Pedrinelli R (2002) Peripheral vascular disease is associated with abnormal arteriolar diameter relationships at bifurcations in the human retina. Clin Sci (Lond) 103, 111-116. 
[152] Stanton AV, Wasan B, Cerutti A, Ford S, Marsh R, Sever PP, Thom SA, Hughes AD (1995) Vascular network changes in the retina with age and hypertension. J Hypertens 13, 1724-1728.

[153] Resnikoff S, Pascolini D, Etya'ale D, Kocur I, Pararajasegaram R, Pokharel GP, Mariotti SP (2004) Global data on visual impairment in the year 2002. Bull World Health Organ 82, 844-851.

[154] Tamura H, Kawakami H, Kanamoto T, Kato T, Yokoyama T, Sasaki K, Izumi Y, Matsumoto M, Mishima HK (2006) High frequency of open-angle glaucoma in Japanese patients with Alzheimer's disease. Journal of the Neurological Sciences 246, 79-83.

[155] Estermann S, Daepp GC, Cattapan-Ludewig K, Berkhoff M, Frueh BE, Goldblum D (2006) Effect of oral donepezil on intraocular pressure in normotensive Alzheimer patients. J Ocul Pharmacol Ther 22, 62-67.

[156] Johnson LV, Leitner WP, Rivest AJ, Staples MK, Radeke MJ, Anderson DH (2002) The Alzheimer's A beta -peptide is deposited at sites of complement activation in pathologic deposits associated with aging and age-related macular degeneration. Proc Natl Acad Sci U S A 99, 11830-11835.

[157] Luibl V, Isas JM, Kayed R, Glabe CG, Langen R, Chen J (2006) Drusen deposits associated with aging and age-related macular degeneration contain nonfibrillar amyloid oligomers. The Journal of Clinical Investigation 116, 378-385.

[158] Anderson DH, Talaga KC, Rivest AJ, Barron E, Hageman GS, Johnson LV (2004) Characterization of [beta] amyloid assemblies in drusen: the deposits associated with aging and age-related macular degeneration. Experimental Eye Research 78, 243256.

[159] Dentchev T, Milam AH, Lee VMY, Trojanowski JQ, Dunaief JL (2003) Amyloid- $\beta$ is found in drusen from some age-related macular degeneration retinas, but not in drusen from normal retinas1 1 Edited by Hans E. Grossniklaus, MD. American journal of ophthalmology 136, 787.

[160] Viestenz A, Langenbucher A, Mardin CY (2006) [Parapapillary autofluorescence as indicator for glaucoma]. Klin Monatsbl Augenheilkd 223, 315-320. 
Table 1: Reported Ocular Changes in AD

\begin{tabular}{|c|c|c|c|c|}
\hline Part of the eye & Reported Ocular Changes in AD & Journal (Year) & Ref. & $N(\mathrm{AD}$, Control) \\
\hline \multirow[t]{9}{*}{ Pupil } & \multirow[t]{9}{*}{ Enhanced pupil response to cholinergic drops } & Science (1994) & [69] & 19,32 \\
\hline & & Neuroreport (1996) & [78] & 25,24 \\
\hline & & J Neurol Neurosurg Psych (1994) & [70] & 26,23 \\
\hline & & Neurobiol Aging (2003) & [72] & 14,30 \\
\hline & & Acta Neurol Scand (1996) & [73] & 24,50 \\
\hline & & Neuropsychobiology (1999) & {$[74]$} & 29,29 \\
\hline & & Biol Psychiatry (1997) & [75] & 67,80 \\
\hline & & Rev Neurol (1996) & [76] & 10,20 \\
\hline & & Nippon Ronen Igakkai Zasshi (1996) & [77] & 53,29 \\
\hline \multirow[t]{4}{*}{ Pupil } & \multirow[t]{4}{*}{ Altered pupil flash response } & Aging Clin Exp Res (2007) & [100] & 23,23 \\
\hline & & Int J Psychophysiol (2000) & [101] & 10,5 \\
\hline & & Int J Psychophysiol (2003) & [91] & 15,30 \\
\hline & & J Neurol Neurosurg Psych (1997) & [102] & 9,9 \\
\hline Lens & Aggregation of $A \beta$, Supra-nuclear cataract & Lancet (2003) & [106] & 9,8 \\
\hline Retina & Narrow retinal veins and decreased venular blood flow & Invest Ophthalmol Vis Sci (2007) & [120] & 9,8 \\
\hline \multirow[t]{2}{*}{ Retina } & \multirow[t]{2}{*}{ Retinal Nerve Fiber Layer (RNFL) thinning } & Invest Ophthalmol Vis Sci (2007) & [120] & 9,8 \\
\hline & & Neurosci Lett (2007) & [119] & 26,38 \\
\hline \multirow[t]{3}{*}{ Retina } & \multirow[t]{3}{*}{ RNFL abnormalities and cell loss } & Acta Neurol Scand (1996) & [121] & 26,23 \\
\hline & & Archives of Ophthalmology (1991) & [122] & 26,30 \\
\hline & & Neurology (2006) & [123] & 40,50 \\
\hline \multirow[t]{2}{*}{ Retina } & \multirow[t]{2}{*}{ Abnormal pattern electroretinogram (PERG) } & Ann Neurol (1989) & [137] & 6,6 \\
\hline & & Ann Neurol (1989) & [138] & 13,30 \\
\hline \multirow[t]{3}{*}{ Optic Disc } & Optic disc pallor, pathologic disc cupping, and & Acta Neurol Scand (1996) & [121] & 26,23 \\
\hline & \multirow[t]{2}{*}{ thinning of the neuro-retinal rim } & Archives of Ophthalmology (1991) & [122] & 30,32 \\
\hline & & Neurology (2006) & [123] & 40,50 \\
\hline
\end{tabular}




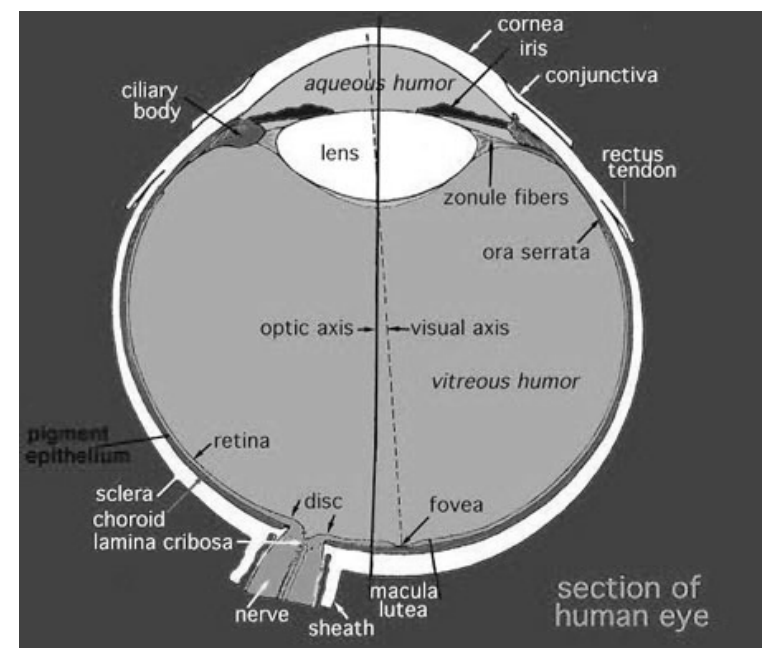

Figure 1: Cross-section of the human eye

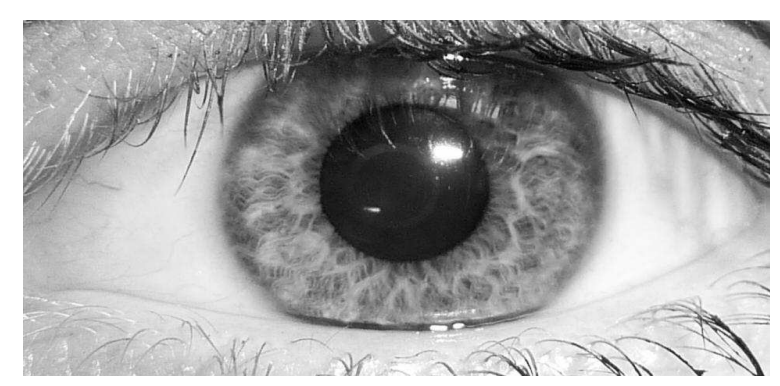

(a)

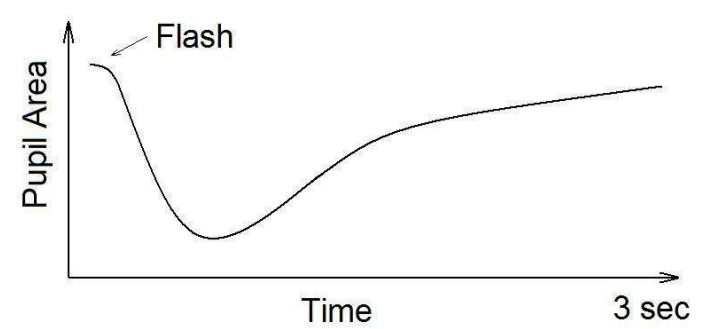

(b)

Figure 2. (a) The human eye. The pupil is the central transparent aperture (appearing as black), surrounded by the iris. (b) The graph of a pupil flash response, showing the pupil contraction resulting from a bright flash of white light. 


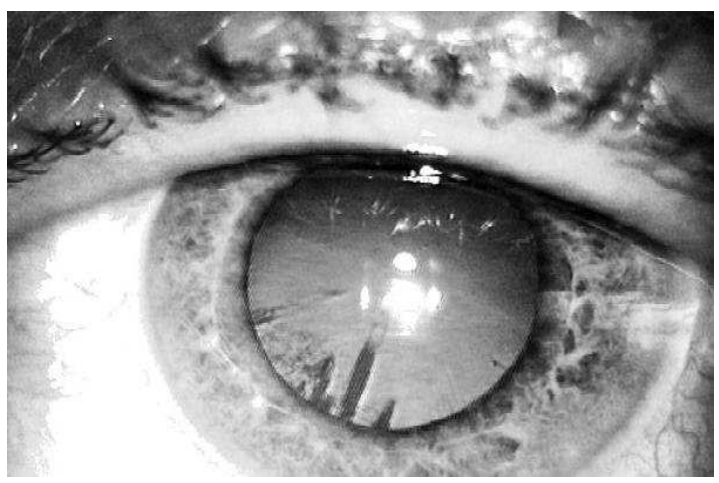

Figure 3. Retro-illumination photograph of a lens with cataract, pupil dilated with tropicamide eye drops. A different type of cataract has been linked with Alzheimer's disease.

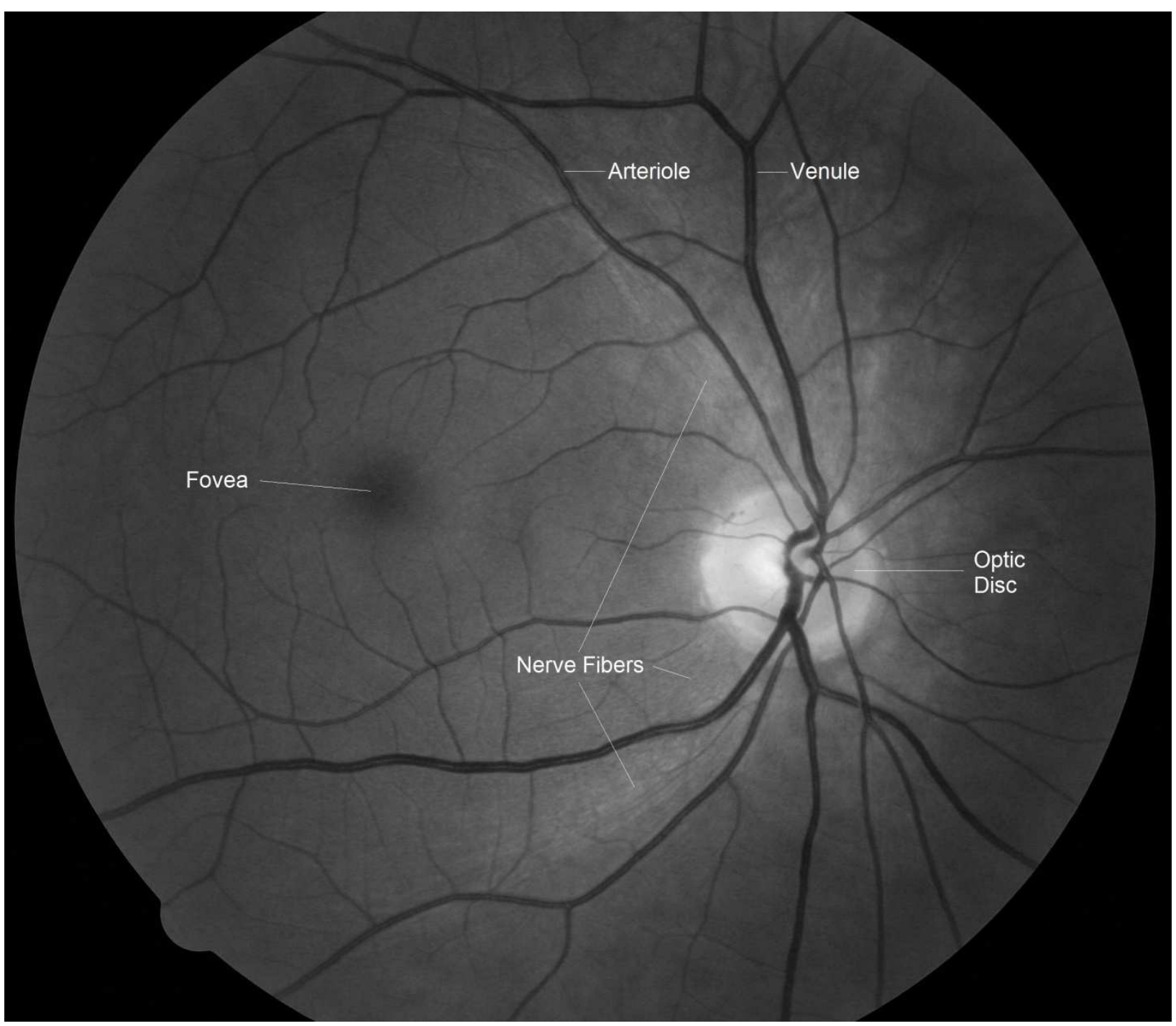


Figure 4. Digital retinal photograph displaying the optic disc in centre, with retinal arterioles and venules (darker) and lightly opaque retinal nerve fibers coursing to the optic disc.

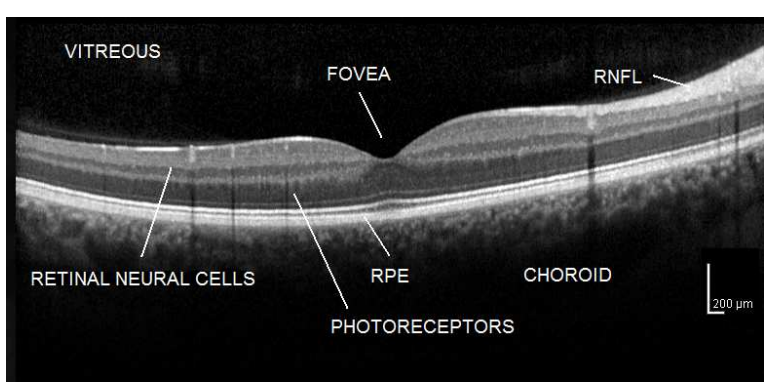

Figure 5. OCT scan showing the retinal layers around the fovea. The layer closest to the vitreous humour is the retinal nerve fiber layer (RNFL) which contains fibers emerging from the retinal ganglion cells below. Also just beneath the RNFL is the retinal vasculature (evident from the vertical shadows cast in this OCT scan). Beneath the retinal ganglion cells are the bipolar, amacrine and horizontal cells, followed by a layer of photoreceptor cells. The photoreceptor cells are nourished by the deeper retinal pigment epithelium and a rich posterior vascular layer called the choroid. OCT scan courtesy of Chris Barry, Lions Eye Institute, Perth, Australia.

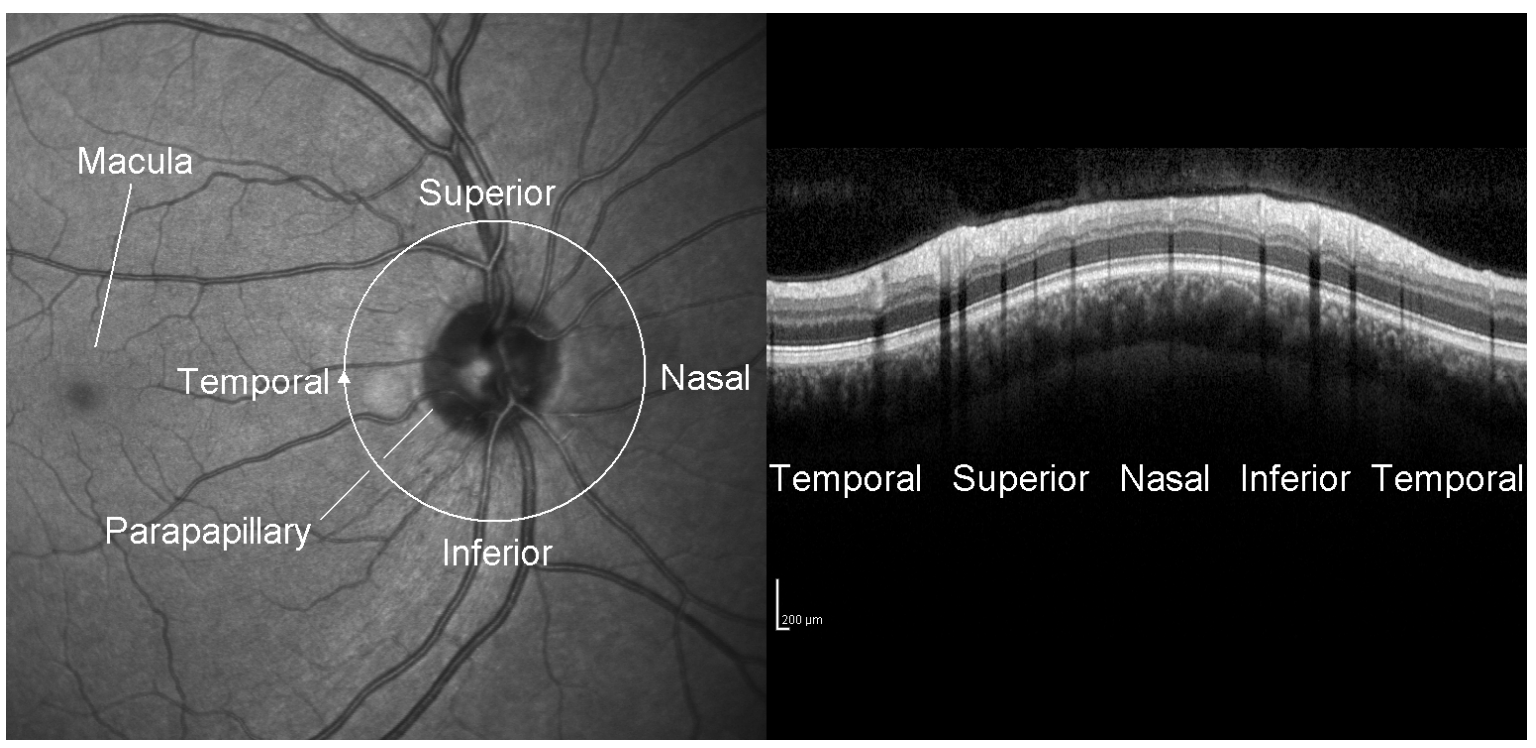


Figure 6. OCT scan circling the optic disc. The image on the right shows the retinal layers detected in an OCT scan traversing a circular path around the optic disc, as illustrated in the retinal photograph on the left. The RNFL is thickest in the superior and inferior quadrants. RNFL studies in AD have had varying results, indicating superior, general, macular or parapapillary thinning. OCT scan courtesy of Chris Barry, Lions Eye Institute, Perth, Australia.

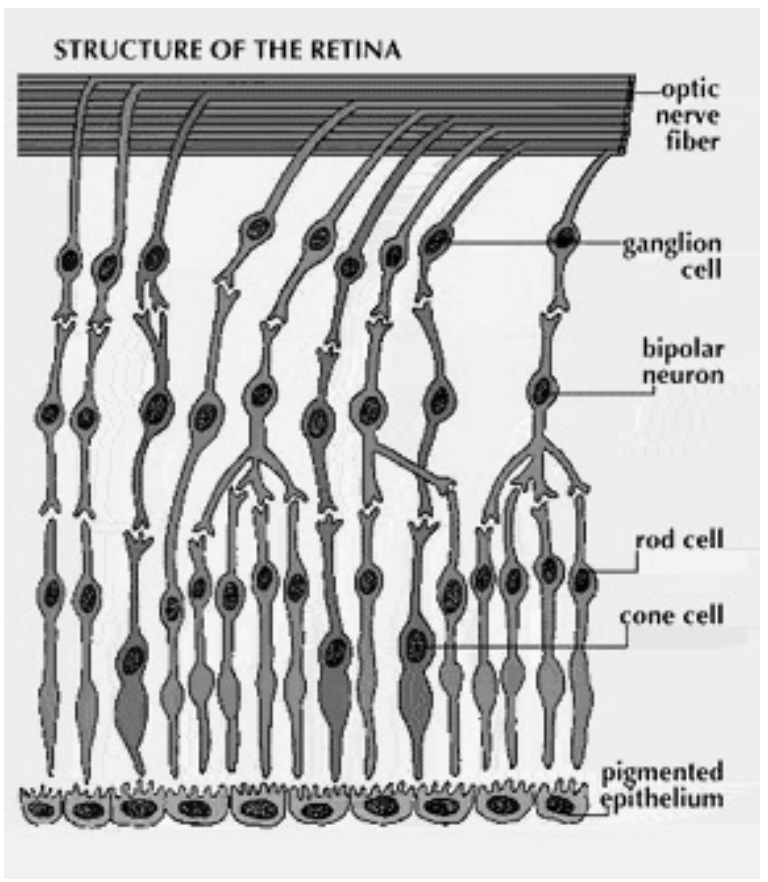

Figure 7: Layers of cells in the retina. Light must pass through the retinal nerve fiber layer and retinal neural cells (ganglion, bipolar, etc.) before reaching the photoreceptor cells (rods and cones). 